\title{
Competition for hydrogen by human faecal bacteria: evidence for the predominance of methane producing bacteria
}

\author{
A Strocchi, J K Furne, C J Ellis, M D Levitt
}

\begin{abstract}
Studies of sludge have shown that some species of sulphate reducing bacteria outcompete methane producing bacteria for the common substrate $\mathrm{H}_{2}$. A similar competition may exist in human faeces where the methane $\left(\mathrm{CH}_{4}\right)$ producing status of an individual depends on the faecal concentration of sulphate reducing bacteria. To determine if nonmethanogenic faeces outcompete $\mathrm{CH}_{4}$ producing faeces for $\mathrm{H}_{2}$, aliquots of each type of faeces were incubated alone or mixed together, with or without addition of $10 \% \mathrm{H}_{2}$ and/or $20 \mathrm{mmol} / \mathrm{l}$ sulphate. Methane producing faeces consumed $\mathrm{H}_{2}$ significantly more rapidly and reduced faecal $\mathrm{H}_{2}$ tension to a lower value compared with non-methanogenic faeces. The mixture of the two types of faeces yielded significantly more $\mathrm{CH}_{4}$ than $\mathrm{CH}_{4}$ producing faeces alone (mean (SD) $8.5(1.3)$ v $2.9(0.45)$ $\mathrm{mmol} / \mathrm{l}$ of homogenate per 24 hours, $\mathrm{p}<0.01$ ). Faecal sulphide concentrations were similar in $\mathrm{CH}_{4}$ producing and non-producing homogenates both before and after 24 hours of incubation. The addition of sulphate to the homogenates did not significantly influence $\mathrm{CH}_{4}$ production or sulphide formation. Our results suggest that in human faeces methane producing bacteria outcompete other $\mathrm{H}_{2}$ consuming bacteria for $\mathrm{H}_{2}$.
\end{abstract}

Methane $\left(\mathrm{CH}_{4}\right)$, a metabolic product of a group of anaerobic bacteria, is excreted consistently in appreciable quantity by some subjects but not others. In various population groups the prevalence of $\mathrm{CH}_{4}$ excretors has been found to range from $24 \%{ }^{1}$ to $95 \%$. $^{2}$ Since $\mathrm{CH}_{4}$ is not metabolised in man, the ability of subjects to excrete this gas reflects the number or activity, or both, of the methanogenic flora present in the colon. ${ }^{3}$ Why only select subjects harbour a $\mathrm{CH}_{4}$ producing flora has piqued the interest of numerous investigators.

The sole source of energy of most species of methane producing bacteria is via the oxidation of $\mathrm{H}_{2}$ produced by other organisms and the activity of methanogens is limited by low $\mathrm{H}_{2}$ availability. ${ }^{46}$ Methanogenesis consumes 4 moles of $\mathrm{H}_{2}$ to reduce 1 mole of $\mathrm{CO}_{2}$ to $\mathrm{CH}_{4}$, a process that greatly reduces the volume of gas that would otherwise be present in the colon. Thus, understanding the factors that regulate the activity of the $\mathrm{CH}_{4}$ producing flora could provide both clinically relevant information with regard to flatulence, as well as basic knowledge concerning the factors that regulate the proliferation and/or activity of colonic bacteria.
Sulphate reducing bacteria (SRB) also use $\mathrm{H}_{2}$ to reduce sulphate to sulphide, and studies of sludge and sediments have shown the SRB outcompete methane producing bacteria for $\mathrm{H}_{2}$ when adequate sulphate is available. ${ }^{46}$ As a result, the presence of a high concentration of SRB limits methanogenesis. The mystery of why some subjects consistently excrete $\mathrm{CH}_{4}$, while others do not, was apparently solved by Gibson and co-workers who carried out a number of studies suggesting that a similar competition between methane producing bacteria and SRB exists in the human colonic lumen. ${ }^{7-9}$ Thus the inability of a subject to excrete $\mathrm{CH}_{4}$ apparently reflects the presence of a non-methanogenic colonic flora that outcompete methane producing bacteria for $\mathrm{H}_{2}$.

If this hypothesis were correct, it follows that $\mathrm{CH}_{4}$ formation by $\mathrm{CH}_{4}$ producing faeces should be reduced appreciably by admixture with nonmethanogenic faeces, and this reduction should be reversed in the presence of a large excess of $\mathrm{H}_{2}$. This concept was tested in the present study by incubating $\mathrm{CH}_{4}$ producing and non-methanogenic faeces, individually or mixed together, with and without the addition of $\mathrm{H}_{2}$ and/or sulphate. Surprisingly, we found that methanogenesis actually was enhanced by the presence of non-methanogenic faeces, even when large quantities of sulphate were provided for SRB metabolism.

\section{Methods}

FAECAL HOMOGENATES

We studied faeces from eight healthy adult volunteers who were all on a conventional diet and who had not taken antibiotics during the two months before the study. On the basis of previous results, faeces of four of them were known to produce large quantities of $\mathrm{CH}_{4}$, while faeces of the other four produced little or no $\mathrm{CH}_{4}$.

Faecal homogenates were prepared by homogenising faeces $(1: 5 \mathrm{w} / \mathrm{v})$ in $0.1 \mathrm{M}$ phosphate buffer $(\mathrm{pH} \mathrm{7 \cdot 0)}$. Strict anaerobiosis was maintained during the procedure and all vessels, syringes, and solutions were exhaustively purged with argon before use. The four $\mathrm{CH}_{4}$ producing faecal samples were paired with the four nonproducing samples and a series of four experiments were then carried out in which faeces from the producer and the non-producer were incubated singly or mixed together. Incubations were carried out in $1250 \mathrm{ml}$ gas-tight syringes sealed with stopcocks. Four syringes contained $5 \mathrm{ml}$ aliquots of the $\mathrm{CH}_{4}$ producing homogenate plus $5 \mathrm{ml}$ of phosphate buffer, four 
Figure 1: Hydrogen consumption (normalised for $\mathrm{PH}_{2}$ ) by $\mathrm{CH}_{4}$ producing faeces (O), nonmethanogenic faeces $(O)$, and by the mixture of the two types of faeces $(\triangle)$, during 24 hours of incubation with a gas space containing an initial $\mathrm{H}_{2}$ concentration of $10 \%$. The graph on the right shows the results obtained when the homogenates were supplemented with $20 \mathrm{mM}$ $\mathrm{Na}_{2} \mathrm{SO}_{4}$. Data are

represented as mean (SEM).
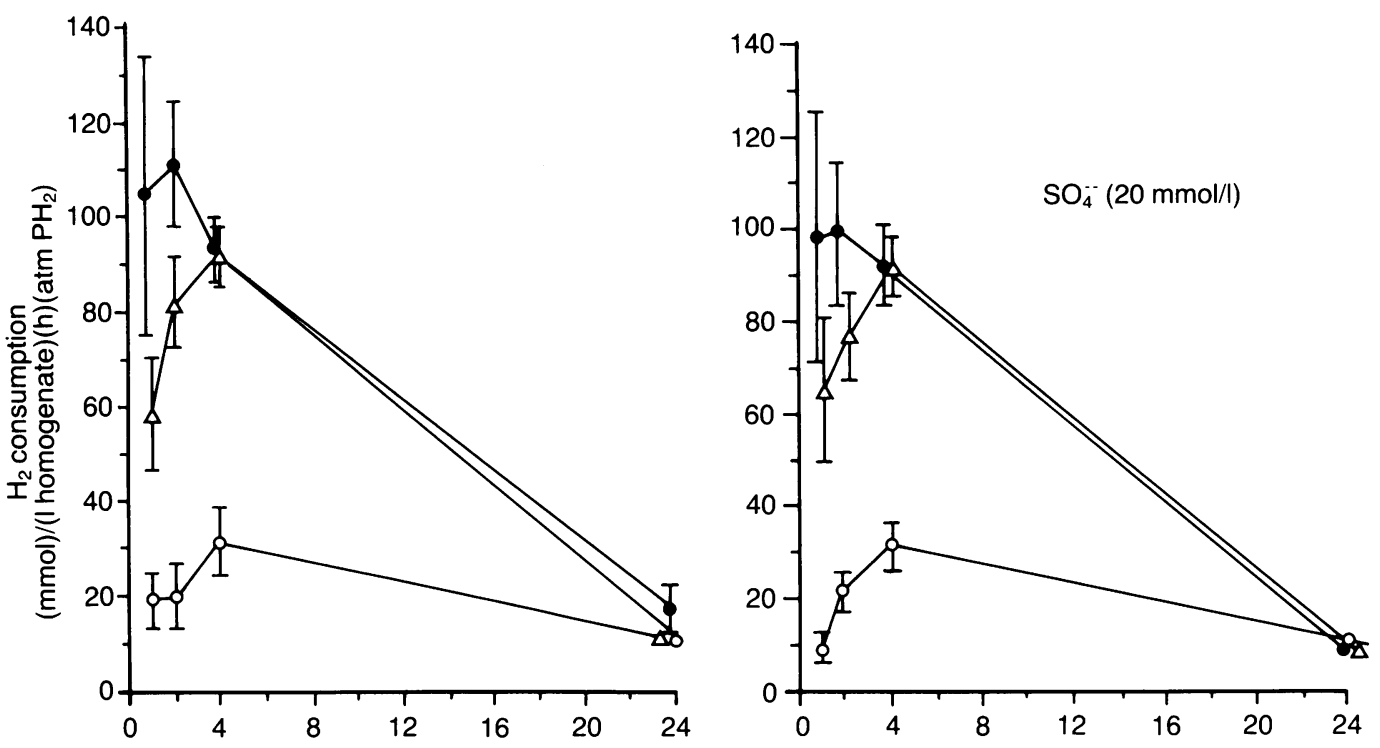

Time (hours)

contained $5 \mathrm{ml}$ aliquots of the non-methanogenic homogenate plus $5 \mathrm{ml}$ of phosphate buffer, and four contained $10 \mathrm{ml}$ of a mixture $(1: 1)$ of the two types of faeces. One of the following was then added to one of the four syringes that comprised the above sets: (a) argon $(30 \mathrm{ml}) ;(b) \mathrm{H}_{2}(3 \mathrm{ml})$ and $\operatorname{argon}(27 \mathrm{ml})$; (c) $20 \mathrm{mM} \mathrm{Na}_{2} \mathrm{SO}_{4}$ and argon $(30 \mathrm{ml})$; or (d) $20 \mathrm{mM} \mathrm{Na} 2 \mathrm{SO}_{4}, \mathrm{H}_{2}(3 \mathrm{ml})$ and argon $(27 \mathrm{ml})$. A rubber sleeve attached to a septum was slipped over the male end of the stopcock. At the time of removal of a gas sample from the syringe, the stopcock was turned from the position where the syringe was sealed, to a position where the syringe was open to the septum. A 21 gauge needle (attached to a $1 \mathrm{ml}$ syringe) was then inserted through the septum and the stopcock into the gas space of the syringe, and a $1 \mathrm{ml}$ gas sample was obtained.

Incubation was carried out at $37^{\circ} \mathrm{C}$ on a rotating wheel. Gas samples were obtained for analysis at $0,1,2,4$, and 24 hours of incubation. Aliquots of each homogenate were collected before and after 24 hours of incubation for sulphide analysis; $12 \%$ zinc acetate was anaerobically added to each aliquot in a ratio of $1: 4$ to prevent oxidation of sulphide.

\section{ANALYSES}

Gas samples were analysed for $\mathrm{H}_{2}$ and $\mathrm{CH}_{4}$ within six hours of collection using a gas chromatograph equipped with a molecular sieve column, a reduction detector for $\mathrm{H}_{2}$, and a flame ionisation detector for $\mathrm{CH}_{4}$.

The method of Cline for the measurement of sulphide in water was modified for faecal sulphide measurements. ${ }^{10}$ Briefly, the homogenate was diluted 1:20 with distilled water and three aliquots of $0.909 \mathrm{ml}$ were used. The first aliquot, that was treated with $0.72 \mu \mathrm{l}$ of $50 \% \mathrm{HCl}$ and vigorously stirred for 30 minutes to drive off all sulphide, served as a blank. The second was spiked with $18 \cdot 2 \mu \mathrm{l}$ of zinc acetate-sodium sulphide standard $(2.6 \mathrm{mM})$ to evaluate sulphide recovery. The third aliquot was used for the determination of sulphide content of the speci- men. The colorimetric reaction was carried out in $1.5 \mathrm{ml}$ Eppendorf tubes that were immediately sealed following the addition of $0.80 \mu \mathrm{l}$ of diamine-ferric chloride reagent made up in 50\% $\mathrm{HCl}$. At the time of reagent addition, $50 \% \mathrm{HCl}$ $(0.72 \mu \mathrm{l})$ was added to aliquots two and three and zinc acetate solution $(18.2 \mu \mathrm{l})$ was added to aliquots one and three. After 30 minutes of incubation at room temperature, samples were centrifuged at $12000_{\mathrm{g}}$ for three minutes and the absorbance of the supernatant was spectrophotometrically determined at $670 \mathrm{~m} \mu$. Percentage recovery of sulphide from spiked aliquots averaged $87 \%$ (range $73-99 \%$ ). Sulphide concentration of a given sample of homogenate was calculated from the optical density of the sample minus that of the $\mathrm{HCl}$ treated sample, corrected for the percentage recovery determined from the spiked sample.

\section{CALCULATIONS}

The volume of $\mathrm{H}_{2}$ or $\mathrm{CH}_{4}$ present at any time point was calculated from the concentration of the respective gas and the volume of gas present in the syringe, plus the volume of $\mathrm{H}_{2}$ or $\mathrm{CH}_{4}$ calculated to have been previously removed for analysis. The consumption rate of $\mathrm{H}_{2}$, determined from samples incubated with $10 \% \mathrm{H}_{2}$, was normalised for $\mathrm{H}_{2}$ tension $\left(\mathrm{PH}_{2}\right)$ and expressed as $\mu \mathrm{mol} / \mathrm{hour}$ per litre of homogenate per atmosphere of $\mathrm{PH}_{2}$. The $\mathrm{PH}_{2}$ of a given time period was considered equal to the arithmetic mean of the $\mathrm{H}_{2}$ tensions at the beginning and end of the time period. Data were expressed as mean (SEM). Statistical analyses for significance were performed using the Student $t$ tests for paired and for unpaired data.

\section{Results}

Figure 1 shows mean $\mathrm{H}_{2}$ consumption (normalised for $\mathrm{PH}_{2}$ ) by $\mathrm{CH}_{4}$ producing faeces, nonmethanogenic faeces, and the mixture of the two, in the absence and presence of additional $\mathrm{Na}_{2} \mathrm{SO}_{4}$. Methane producing faeces consumed 
Methane formation ${ }^{\star}$ by $\mathrm{CH}_{4}$ producing faeces, non-methanogenic faeces, and by the mixture of the two during incubation with and without addition of $\mathrm{H}_{2}$ and/or $\mathrm{Na}_{2} \mathrm{SO}_{4}$

\begin{tabular}{|c|c|c|c|c|c|}
\hline \multirow[b]{2}{*}{ Faeces } & \multirow[b]{2}{*}{$\begin{array}{l}\text { Incubation } \\
\text { (hours) }\end{array}$} & \multicolumn{4}{|l|}{ Substrate added } \\
\hline & & None & $\begin{array}{l}\mathrm{H}_{2} \\
(10 \%)\end{array}$ & $\begin{array}{l}\mathrm{Na}_{2} \mathrm{SO}_{4} \\
(20 \mathrm{mM})\end{array}$ & $\begin{array}{l}\mathrm{H}_{2}+\mathrm{Na}_{2} \mathrm{SO}_{4} \\
(10 \%)(20 \mathrm{mM})\end{array}$ \\
\hline $\mathrm{CH}_{4}$ producing & $\begin{array}{r}1 \\
2 \\
4 \\
24\end{array}$ & $\begin{array}{l}0.30(0.09) \\
0.54(0.14) \\
0.99(0.22) \\
2.88(0.45)\end{array}$ & $\begin{array}{l}1.35(0.38) \\
1.98(0.50) \\
2.66(0.41) \\
4.37(0.38)\end{array}$ & $\begin{array}{l}0.23(0.054) \\
0.43(0.099) \\
0.77(0.14) \\
2.25(0.32)\end{array}$ & $\begin{array}{l}1 \cdot 26(0.0045) \\
1 \cdot 89(0.50) \\
2 \cdot 57(0.45) \\
4 \cdot 14(0.45)\end{array}$ \\
\hline Non-methanogenic & $\begin{array}{r}1 \\
2 \\
4 \\
4 \\
24\end{array}$ & $\begin{array}{l}0.0(0.0) \\
0.0(0.0) \\
\text { ND } \\
0.013(0.012)\end{array}$ & $\begin{array}{l}0.0(0.0) \\
\text { ND } \\
\text { ND } \\
\text { ND }\end{array}$ & $\begin{array}{l}0.0(0.0) \\
\text { ND } \\
\text { ND } \\
0.0027(0.0026)\end{array}$ & $\begin{array}{l}\text { ND } \\
0.0059(0.0045) \\
0.0086(0.0068) \\
0.020(0.011)\end{array}$ \\
\hline Mixture & $\begin{array}{r}1 \\
2 \\
4 \\
24\end{array}$ & $\begin{array}{l}0.68(0.15) \\
1.26(0.18) \\
2.30(0.13) \\
8.55(1.26)\end{array}$ & $\begin{array}{c}1.22(0.36) \\
2.16(0.54) \\
3.87(0.54) \\
10.4(1.3)\end{array}$ & $\begin{array}{l}0.72(0.18) \\
1.22(0.25) \\
2.12(0.36) \\
7.20(1.49)\end{array}$ & $\begin{array}{l}1.35(0.54) \\
2.25(0.54) \\
3.51(0.72) \\
8.55(1.62)\end{array}$ \\
\hline
\end{tabular}

$\star$ Data are expressed as average $(\mathrm{SEM})$ in $\mathrm{mmol} / \mathrm{l}$ homogenate.

$\mathrm{ND}=<0.0045 \mathrm{mmol} \mathrm{CH}_{4} / \mathrm{l}$ of homogenate.

$\mathrm{H}_{2}$ significantly more rapidly than non-methanogenic faeces during the time periods $0-1$ hour $(\mathrm{p}<0.05), 1-2$ hours $(\mathrm{p}<0.001)$, and $2-4$ hours $(\mathrm{p}<0.001)$. The mixture of the homogenates had a $\mathrm{H}_{2}$ consumption rate comparable to that of $\mathrm{CH}_{4}$ producing faeces, and significantly $(\mathrm{p}<0.01)$ higher than that of non-methanogenic faeces at 1,2 , and 4 hours of incubation. The addition of $\mathrm{Na}_{2} \mathrm{SO}_{4}$ had no statistically significant effect on $\mathrm{H}_{2}$ consumption by any of the homogenates at any sampling time. After 24 hours of incubation the $\mathrm{PH}_{2}$ of the $\mathrm{CH}_{4}$ producing homogenates $(1950(325) \mathrm{ppm})$ was much lower $(\mathrm{p}<0.0001)$ than that of the non-methanogenic homogenates (39200 (4600) ppm). The $\mathrm{PH}_{2}$ reached in the mixture of homogenates (2900 (450) ppm) was comparable to that of the $\mathrm{CH}_{4}$ producing homogenates and significantly lower $(p<0.0001)$ than that of non-methanogenic homogenates. Similar results were obtained in the presence of added $\mathrm{Na}_{2} \mathrm{SO}_{4}$.

The mean $\mathrm{CH}_{4}$ production by the different incubates is summarised in the Table. Trivial $\mathrm{CH}_{4}$ production occasionally was observed in faeces considered to be non-methanogenic, but the highest value did not exceed $1 \%$ of the values
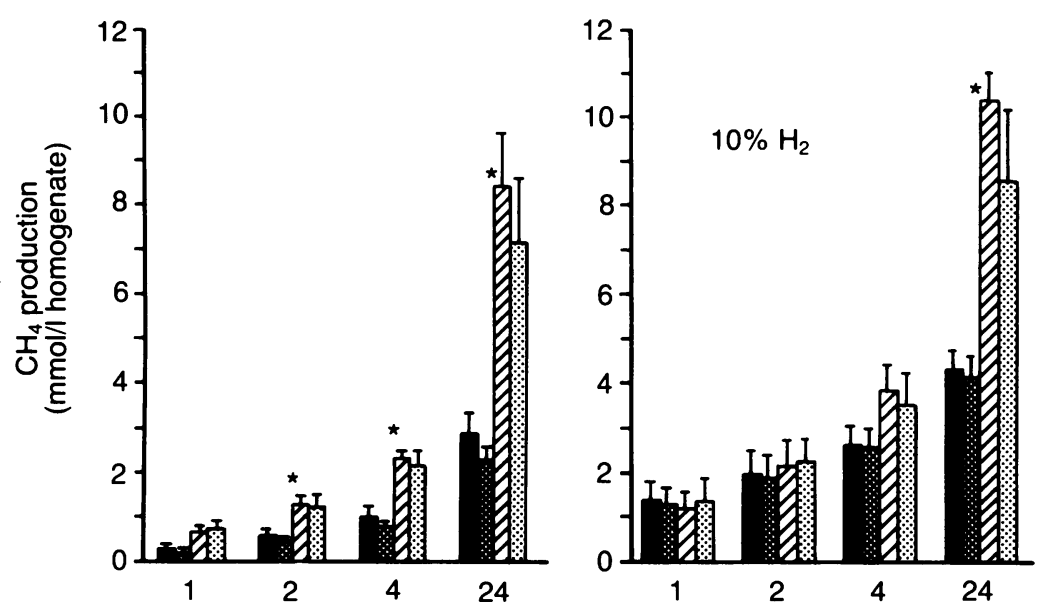

Time (hours)

Figure 2: Methane production (mean (SEM)) by faecal homogenates during 24 hours of incubation without (left) and with $10 \% \mathrm{H}_{2}$ (right). From left to right, the four bars at each time point respectively represent: (a) $\mathrm{CH}_{4}$ producing faeces without supplement; (b) $\mathrm{CH}_{4}$ producing faeces supplemented with 20 mmol/l $\mathrm{NA}_{2} \mathrm{SO}_{4} ;$ (c) mixture of $\mathrm{CH}_{4}$ producing faeces with nonmethanogenic faeces without supplement; $(d)$ mixture of $\mathrm{CH}_{4}$ producing faeces with nonmethanogenic faeces supplemented with $20 \mathrm{mmol} / \mathrm{l} \mathrm{Na} \mathrm{SO}_{4}$. Asterisks indicate a significant difference $(p<0.02)$ between the $\mathrm{CH}_{4}$ producing homogenates and the mixture. observed with $\mathrm{CH}_{4}$ producing faeces or with the mixture. This very low production was not significantly enhanced by the addition of $10 \% \mathrm{H}_{2}$ to the gas space, in contrast to the increase found with $\mathrm{CH}_{4}$ producing homogenates.

In the absence of added $\mathrm{H}_{2}, \mathrm{CH}_{4}$ formation by $\mathrm{CH}_{4}$ producing faeces was not inhibited by admixture with non-methanogenic faeces, but rather was enhanced in each of the four pairs of homogenates. This enhancement was statistically significant after 2, 4 and 24 hours of incubation (Fig 2). When $\mathrm{H}_{2}$ was added, the increase in $\mathrm{CH}_{4}$ production was statistically significant only after 24 hours. The addition of $\mathrm{Na}_{2} \mathrm{SO}_{4}$ had no significant effect on $\mathrm{CH}_{4}$ production by any of the homogenates (Fig 2 and Table).

Before incubation, sulphide concentration averaged $0 \cdot 18(0 \cdot 043) \mathrm{mM}$ for non-methanogenic faeces and $0.15(0.047) \mathrm{mM}$ for $\mathrm{CH}_{4}$ producing faeces (NS). Compared to the non-supplemented homogenates, neither the addition of $10 \% \mathrm{H}_{2}$, $\mathrm{Na}_{2} \mathrm{SO}_{4}$, nor both significantly influenced sulphide concentrations (Fig 3) after 24 hours of incubation. The tendency for faecal sulphide concentration to increase with incubation did not reach statistical significance in either the $\mathrm{CH}_{4}$ producing or non-methanogenic homogenates. The greatest increase $(0 \cdot 17 \mathrm{mmol} / 1$ homogenate $)$ was found in $\mathrm{CH}_{4}$ producing faeces supplemented with sulphate. This sulphide production would have consumed only about one twentieth of the $\mathrm{H}_{2}$ consumed via $\mathrm{CH}_{4}$ formation.

\section{Discussion}

The findings of our study sharply contrast with previous reports $^{7-9}$ 11 suggesting that the absence of $\mathrm{CH}_{4}$ production in the colon of certain individuals reflects the presence of high concentrations of organisms, such as SRB, that outcompete methanogens for $\mathrm{H}_{2}$. These reports have shown that $\mathrm{CH}_{4}$ producing faeces usually contained less than $10^{7} \mathrm{SRB} / \mathrm{g}$ dry weight while non-methanogenic faeces always contained more than $10^{7}$ $\mathrm{SRB} / \mathrm{g}$ dry weight," 11 and that the sulphide concentration of $\mathrm{CH}_{4}$ producing faeces was much lower than that of non-methanogenic faeces. ${ }^{9}$ In addition, incubation of $\mathrm{CH}_{4}$ producing with non-methanogenic faeces was reported to inhibit $\mathrm{CH}_{4}$ formation. ${ }^{7}$

Our study provided two independent lines of evidence that led us to conclude that competition for $\mathrm{H}_{2}$ does not explain why some subjects fail to excrete $\mathrm{CH}_{4}$. First, if a lack of $\mathrm{CH}_{4}$ production reflects very rapid $\mathrm{H}_{2}$ consumption by nonmethanogenic bacteria, one might expect that faeces that did not produce $\mathrm{CH}_{4}$ would consume $\mathrm{H}_{2}$ more efficiently than $\mathrm{CH}_{4}$ producing faeces. To the contrary, we found that added $\mathrm{H}_{2}$ was consumed about five times more rapidly by $\mathrm{CH}_{4}$ producing faeces (see Fig 1). More important, after 24 hours of incubation, $\mathrm{CH}_{4}$ producing faeces reduced the $\mathrm{PH}_{2}$ of the homogenate to one twentieth of that observed in non-methanogenic faeces. Since the two type of faeces have been shown to have similar absolute $\mathrm{H}_{2}$ production rates, ${ }^{12}$ methanogens apparently are able to consume $\mathrm{H}_{2}$ at a lower $\mathrm{PH}_{2}$ than other $\mathrm{H}_{2}$ consuming bacteria. These results agree with the in vivo observation that $\mathrm{CH}_{4}$ producing subjects excrete 


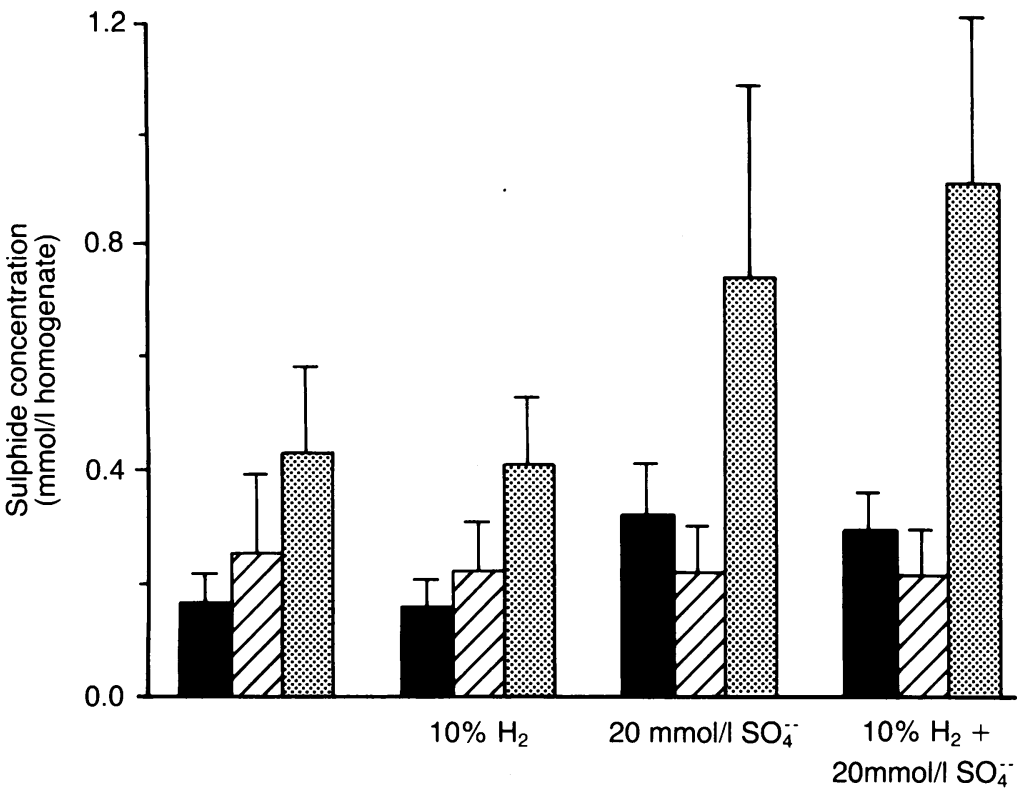

Figure 3: Sulphide concentration (mean (SEM)) after 24 hours of incubation without addition of either $\mathrm{H}_{2}$ or sulphate, or with addition of $10 \% \mathrm{H}_{2}, 20 \mathrm{mmol} / \mathrm{l} \mathrm{Na}_{2} \mathrm{SO}_{4}$, or $10 \% \mathrm{H}_{2}$ plus 20 mmol/l $\mathrm{Na}_{2} \mathrm{SO}_{4}$. From left to right the series of three bars represent: $\mathrm{CH}_{4}$ producing faeces, nonmethanogenic faeces, and the mixture of the two types of faeces.

less $\mathrm{H}_{2}$ than non-producers, both in the fasting state and after ingestion of non-absorbed carbohydrate. ${ }^{1314}$

Second, the addition of non-methanogenic homogenates to $\mathrm{CH}_{4}$ producing homogenates did not inhibit $\mathrm{CH}_{4}$ formation, but indeed, roughly doubled it (see Fig 2). The most likely explanation for this result is provided by the finding that the addition of $\mathrm{H}_{2}$ to the incubates significantly increased $\mathrm{CH}_{4}$ production, indicating that $\mathrm{H}_{2}$ availability was the rate limiting step in methanogenesis. Therefore the enhanced $\mathrm{CH}_{4}$ production observed in the faecal mixture presumably resulted from the ability of the methanogens to pirate the additional $\mathrm{H}_{2}$ liberated from the non-methanogenic homogenate.

While we did not enumerate SRB in our faecal samples, Gibson et $a l^{11}$ demonstrated very high concentrations of these bacteria in the faeces of 17 consecutive subjects who did not produce $\mathrm{CH}_{4}$. Since the rate of $\mathrm{H}_{2}$ consumption by $\mathrm{SRB}$ is dependent on the availability of sulphate, we excluded the possibility that a lack of sulphate was limiting $\mathrm{H}_{2}$ consumption by incubating each pair of homogenates in the presence of $20 \mathrm{mM}$ sulphate. Sulphate addition did not affect the rate of $\mathrm{H}_{2}$ consumption (Fig 1) and did not significantly reduce the rate of $\mathrm{CH}_{4}$ production (Fig 2), although there was a trend in that direction. Therefore, the reported ability of sulphate feeding to stop $\mathrm{CH}_{4}$ production in some subjects ${ }^{15}$ presumably must be attributed to some inhibitory effect on methanogenesis rather than to the provision of substrate for $\mathrm{H}_{2}$ consumption.

Our measurements of sulphide concentrations in freshly passed faeces differed appreciably from results reported by Gibson and co-workers in that our values were roughly 10 times higher and we did not find a significant difference between $\mathrm{CH}_{4}$ producing and non-producing samples. These discrepancies presumably are attributable to our modifications of the standard technique for sulphide measurement in water ${ }^{10}$ that made this technique more suitable for faecal analysis. We also found that the addition of sulphate $(20 \mathrm{mM})$ and/or $\mathrm{H}_{2}(10 \%)$ did not result in a significant increase in faecal sulphide concentration after 24 hours of incubation. Since sulphide may be converted to other compounds in faeces, sulphide concentrations are not a stoichiometric measure of sulphate reduction. However, to the extent that faecal sulphide is a semiquantitative indicator of sulphate reduction, it appears that this reaction may not have been a major route of $\mathrm{H}_{2}$ consumption in our non-methanogenic (or $\mathrm{CH}_{4}$ producing) homogenates.

We conclude that the methane producing bacteria present in human faeces outcompete other $\mathrm{H}_{2}$ consuming organisms for $\mathrm{H}_{2}$. This concept is compatible with the reported inverse relation between the faecal concentration of methane producing bacteria and SRB. However, in contrast to the prevailing hypothesis, the presence or absence of faecal methanogens would regulate $S R B$ concentrations rather than vice versa. The burning question of what factor produces a colonic ecosystem favourable to methanogens still remains a 'mystery inside an enigma' (W S Churchill, unpublished observation, 1939).

This study was supported in part by Veterans Affairs Merit Review Funds and NIDDK no. 2 RO1 DK13309-22.

1 Pitt P, De Bruijn KM, Beeching MF, Goldberg E, Blendis LM. Studies on breath methane: the effect of ethnic orgin LM. Studies on breath methane: the

2 Segal I, Walker ARP, Lord S, Cummings JH. Breath methane and large bowel cancer risk in contrasting African populations. Gut 1988; 29: 608-13.

3 Weaver GA, Krause JA, Miller TL, Wolin MJ. Incidence of methanogenic bacteria in a sigmoidoscopy population: an association of methanogenic bacteria and diverticulosis. Gut 1986; 27: 698-704.

4 Lovley DR, Dwyer DF, Klug MJ. Kinetic analysis of competition between sulfate reducers and methanogens for hydrogen in sediments. Appl Environ Microbiol 1982; 43: 1373-9.

5 Kristjansson JK, Schonheit P, Thauer RK. Different $K_{s}$ values for hydrogen of methanogenic bacteria and sulfate reducing bacteria: an explanation for the apparent inhibition of methanogenesis by sulfate. Arch Microbiol 1982; 131: 278-82.

6 Lupton FS, Zeikus JG. Physiological basis for sulfate-dependent hydrogen competition between sulfidogens and methanogens. Curr Microbiol 1984; 11: 7-12.

7 Gibson GR, Cummings JH, Macfarlane GT. Competition for hydrogen between sulphate-reducing bacteria and methanogenic bacteria from the human large intestine. $\mathcal{J} A p p l$ Bacteriol 1988; 65: 241-7.

8 Gibson GR, Cummings JH, Macfarlane GT. Use of a threestage continuous culture system to study the effect of mucin on dissimilatory sulfate reduction and methanogenesis by on dissimilatory sulfate reduction and methanogenesis by
mixed populations of human gut bacteria. Appl Environ mixed populations of hum

Microbiol 1988; 54: 2750-5.
9 Gibson GR, Cummings JH, Macfarlane GT, et al. Alternative pathways for hydrogen disposal during fermentation in the human colon. Gut 1990; 31: 679-83.

10 Cline JD. Spectrophotometric determination of hydrogen sulfide in natural waters. Limnol Oceanogr 1969; 14: 454-8.

11 Gibson GR, Macfarlane GT, Cummings JH. Occurrence of sulphate-reducing bacteria in human faeces and the relationship of dissimilatory sulphate reduction to md ship of dissimilatory sulphate reduction to methanogenes in the large gut. $f$ Appl Bacteriol 1988; 65: 103-1

Strocchi $A$, Levitt $\mathrm{MD}$. Are varying $\mathrm{H}_{2}$ consumption rates in the colon the major determinant of $\mathrm{H}_{2}$ excretion? Gastroology 1990; 98: A20

13 Bjorneklett A, Jenssen E. Relationships between hydrogen $\left(\mathrm{H}_{2}\right)$ and methane $\left(\mathrm{CH}_{4}\right)$ production in man. Scand f Gastroenterol 1982; 17: 985-92.

14 Cloarec D, Bornet F, Gouilloud S, Barry JL, Salim B, Galmiche JP. Breath hydrogen response to lactulose in healthy subjects: relationship to methane producing status. Gut 1990; 31: 300-4.

15 Christl SU, Gibson GR, Florin THJ, Cummings JH. The role of dietary sulphate in the regulation of methanogenesis in the human large intestine. Gastroenterology 1990; 98: Al64. 